\title{
Nutrition and Cardiovascular Diseases: Programming and Reprogramming
}

\author{
Emiliana Barbosa Marques, ${ }^{\circledR}$ Karyne Pollo de Souza, ${ }^{\circledR}$ Thaís Alvim-Silva, ${ }^{\circledR}$ Ivis Levy Fernandes Martins, ${ }^{\circledR}$ Samuel
} Pedro, ${ }^{\circledR}$ Christianne Bretas Vieira Scaramello ${ }^{\circ}$

Universidade Federal Fluminense, Instituto Biomédico, Niterói, RJ - Brazil

\section{Abstract}

The Developmental Origin of Health and Disease $(\mathrm{DOHaD})$ is an area of science dedicated to studying the processes by which insults during critical periods of mammals development leading to physiological changes resultig in diseases throughout life. Studies point to a complex interaction between nutritional status in early life and cardiovascular system homeostasis in which maternal malnutrition during gestation and/or lactation, as well as early weaning, are associated with development of cardiovascular diseases in adulthood. In this context, epigenetic changes, such as DNA methylation, histone acetylation, and change in microRNA expression have been considered molecular bases of cellular plasticity, which can also be gender-dependent. Experimental studies have demonstrated that interventions encompassing the consumption of functional food/bioactive compounds, as well as energetic and nutrients adjustments on the diet, may attenuate or even prevent consequences associated with plasticity of development, improving cardiovascular health. This review aimed to gather and discuss the findings within this context, published over the last ten years.

\section{Introduction}

Cardiovascular diseases (CVDs) are the main cause of death worldwide and belongs to the group of chronic non-communicable diseases (NCDs).

\section{Keywords}

Cardiovascular Diseases; Nutrition; Pregnancy; Lactation; Functional Food; Epigenomics.
According to the World Health Organization (WHO), approximately 17.9 million people died of CVD in 2016 , nearly $31 \%$ of the total number of deaths in the world. ${ }^{1}$ In Brazil, where the scenario is similar, these diseases are responsible for the highest mortality rates in the same year. ${ }^{2}$ This health public problem results in high costs with treatments and hospitalizations by Brazilian Unified Health System (SUS in Portuguese), in addition to indirect economic impact caused by reduction on productivity and sick absence. ${ }^{3}$

For years, it was believed that CVDs were determined by genetic factors and lifestyle. However, evidences has shown that, in the majority of cases, CVDs in adulthood may be related to the process of cellular plasticity due to nutritional insults during pregnancy and/or lactation. ${ }^{4}$ Experimental studies have proven that mother's nutritional status during the critical periods of development, such as gestation and lactation, as well as early weaning, may favor NCDs programming throughout life. ${ }^{5}$ These studies encompass a new area of science called Developmental Origin of Health and Disease (DOHaD) introduced by David Barker, which investigate the programming of diseases with fetal origins. ${ }^{5-7}$

Currently, it is well-known that the programming of the cardiovascular system can also occur directly in critical stages of life. ${ }^{4}$ Recent studies have illustrated that the differentiation and proliferation of cardiac cells are not entirely complete at birth, continuing in the immediate post-natal period. DNA synthesis of these cells still takes place during the first two weeks of life in rodents and, in human beings, in the first 20 years, making the mammals' hearts vulnerable to insults during intrauterine development as well as during lactation period..$^{8} 9$ Moreover, embryonic and immediate post-natal development periods are stages of life characterized by rapid growth and organs and

Mailing Address: Emiliana Marques

Rua Professor Hernani Pires de Melo, 110. Postal Code: 24220-900, Niterói, RJ - Brazil

E-mail: milibmarques@hotmail.com 
systems maturation. Thus, the lack or excess of nutrients during these periods favors adaptations that look for guarantee of survival in an adverse environment. ${ }^{10}$ The direct impact upon gene expression, stimulating or inhibiting factors that control the cell cycle, mitosis rates, maturity, and cell death alter homeostasis, characterizing the adaptive process of many species. ${ }^{7}$ In this context, epigenetic changes, such as DNA methylation, histone acetylation, and change in the microRNA expression have been considered molecular bases of cell plasticity. ${ }^{11}$

Diets that are inadequate in macro and micronutrients have been identified as an important stimulator of epigenetic processes, especially DNA methylation. ${ }^{12}$ Studies in animal models have demonstrated that maternal malnutrition during the critical periods of development affects the DNA methylation of specific genes, changing the phenotype of the offspring and contributing to the programming of diseases, including cardiometabolic diseases. ${ }^{7,13}$ By contrast, nutritional interventions in these same periods could favor the reprogramming of diseases through similar mechanisms. ${ }^{6,14}$ interventions with bioactive compounds from functional foods may attenuate or even reprogram the physiological changes related to cell plasticity (Figure 1). ${ }^{15}$

Although evidence shows that the sex is an important variable, for various reasons this variable is ignored in many studies conducted primarily with individuals of the male sex. The literature points out differences in gender, regarding the progression, response, and treatment of CVDs, in such a way that studies conducted only with men can lead to incorrect diagnoses and inappropriate therapies. ${ }^{16}$ Thus, it is important to consider that disease development may be influenced by sex, as well as be passed down through generations. ${ }^{18}$ This review aimed to gather the findings about programming and reprogramming of CVDs associated with malnutrition during gestation and/or lactation, as well as about interventions with functional foods/bioactive compounds, addressing whenever possible, sexual dimorfism and physiologic changes passed down through generations. Since epidemiological studies often fail to answer many questions related to developmental plasticity, this review focused in rodents studies. 


\section{Methods}

To conduct this review, a bibliography study was carried out in January 2020 by 05 (five) separate researchers, with a subsequent group discussion. The studies were selected by accessing the Pubmed/MEDLINE and Scielo databases. The terms used in this research sought to gather studies involving cardiometabolic programming/development plasticity, including different animal models (rodents) of maternal malnutrition during gestation and/or lactation, including early weaning, as well as studies involving interventions with functional foods and/or isolated bioactive compounds. This study searched for articles that presented outcomes associated with the risk of development and CVDs, as well as those which had been published over the last ten years. Studies in languages other than Portuguese or English, through the reading of titles and abstracts, were excluded. Finally, some articles were also excluded upon reading the full text.

\section{Results}

Figure 2 illustrates the literature selection process. In total, 848 results were found, of which 799 articles were excluded due to the criteria mentioned above. Therefore, 48 articles were selected as they presented a direct connection to the object of this study.

\section{Maternal malnutrition: lack or excess of macronutrients}

The study including the Dutch Famine, which occurred during World War II, represents a historical milestone for studies involving the origin of diseases related to malnutrition in the early life. This work demonstrated that maternal malnutrition during gestation disrupts the metabolism of the descendants in the long run, resulting in hyperglycemia, a greater incidence of CVD, blood clotting disorders, as well as an increase in the capacity of response to stress and obesity. ${ }^{19}$

According to the $\mathrm{WHO},{ }^{20}$ malnutrition refers to the deficiencies, excesses, or imbalances in the energy and/ or nutrient intake. The inadequate consumption of macronutrients during the critical periods of development has been related to cardiometabolic diseases in one's offspring. ${ }^{21}$ Malnutrition during the intrauterine life associated with maternal food restrictions contributes to a worse performance and a premature phenotype of cardiac aging in adult offspring. Similarly, nutritional

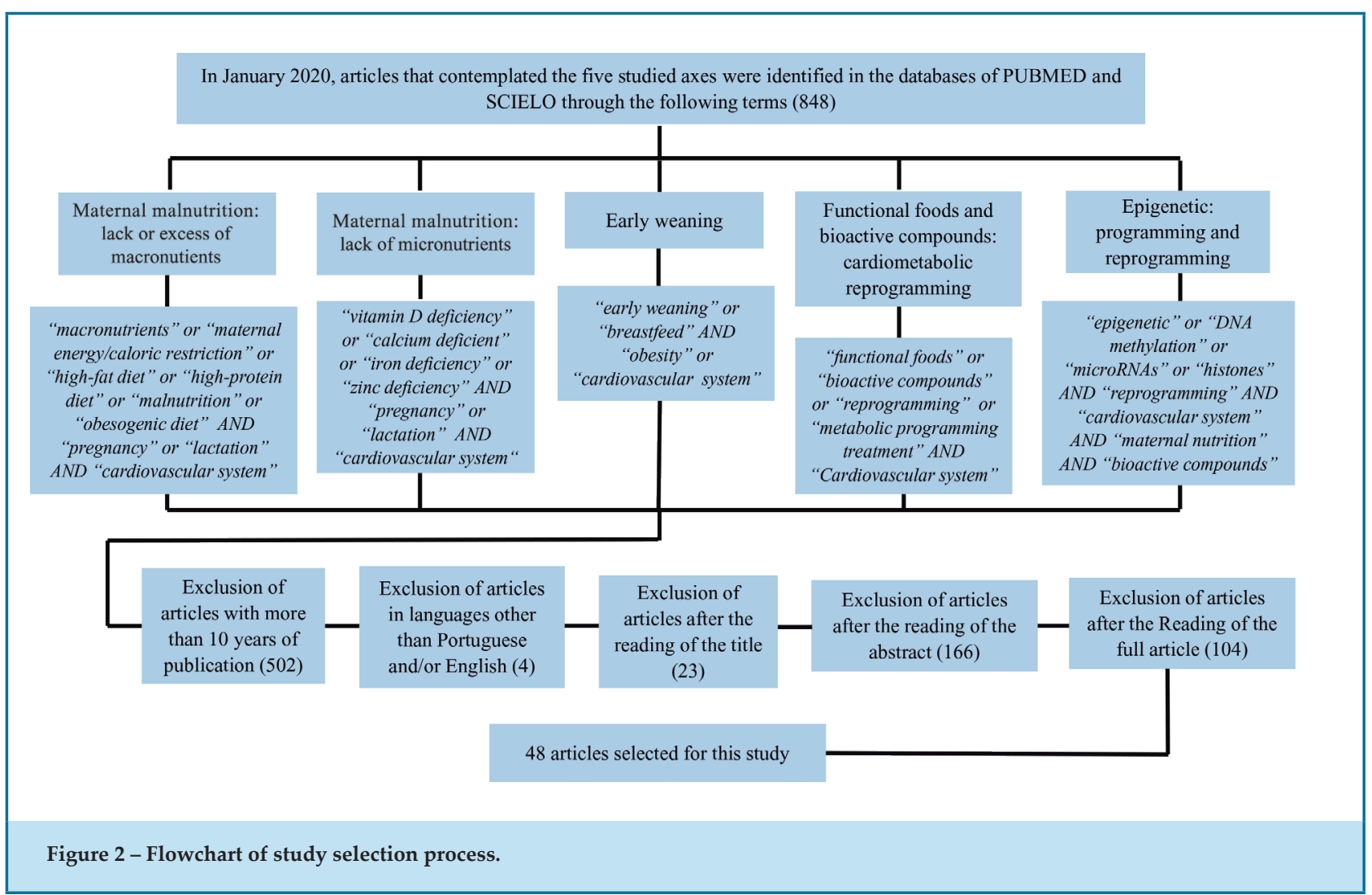


excesses in the early life, associated with maternal obesity can induce the involvement of the descendants' cardiac function over the long term. These exposures alter one's cardiac metabolism and the microRNAs involved in each development stage of the heart and seem to play a crucial role in the unfavorable programming of CVDs. ${ }^{22}$

Thus, diets that are restrictive in macronutrients and/or obesogenic diets, characterized by the excess of calories, sugars, and lipids, can lead to malnutrition and, if consumed by the mother during gestation and/ or lactation, can be equally capable of programming the offspring for cardiometabolic diseases. ${ }^{23}$ Maternal malnutrition (F0 generation) programs its direct descendants (F1 generation), and it is capable of programming its subsequent generations (F2, F3, for example). ${ }^{24}$ Table 1 shows studies, including animal models, which evaluate the consequences, over the long term, of the excess or restriction of macronutrients during these critical periods.

\section{Maternal malnutrition: lack of micronutrients}

The same way as macronutrients, the micronutrients are also essential to biological activity. ${ }^{35}$ Their deficiencies affect many pregnant women and are considered a growing health problem that encompasses nearly 2 billion people worldwide. This condition is also known as hidden hunger, and includes deficiencies of iron, calcium, iodine, folate, and zinc, as well as other lesserknown micronutrients, such as selenium, chromium, and vanadium. ${ }^{36,37}$

The consumption of micronutrients varies widely during gestation and among populations. Women from underdeveloped countries are more exposed to malnutrition during gestation, and the nutritional demands of this period can accentuate the deficiencies of these nutrients, with severe consequences for the health of the mother and the baby. It is currently estimated that $15-20 \%$ of these women suffer from lack of iron, $15 \%$ from lack of vitamin A, and $25 \%$ from lack of zinc. ${ }^{35}$ Micronutrient supplements diminish the risk of low birth weight, small size for the gestational age, and stillbirths due to malnutrition, thus justifying this intervention during pre-natal follow-up. The positive effects of a proper maternal diet regarding micronutrients can persist into childhood, but data is scarce concerning possible benefits in the long run. ${ }^{35}$ Table 2 summarizes the main findings resulting from the need for micronutrients in animal models during critical periods of development.

\section{Early weaning}

Breast milk is the ideal food for a newborn's nutrition. In general, human milk is $87 \%$ water, $7 \%$ lactose, $3.8 \%$ fat and $1 \%$ protein; however, its composition varies during lactation, adapting to the changes needed for the child's growth. ${ }^{46,47}$ Supplementation with infant formula is recommended only for the cases in which exclusive breastfeeding is impossible, unsustainable, or inadequate. In most cases, cow's milk or soy milk is used as a base, complemented with ingredients produced by genetic engineering, which most closely resembles breast milk. Even though the industry's intention is to imitate human milk as closely as possible, the use of infant formulas should only be considered after having depleted all alternative possibilities of breastfeeding. . $^{47,48}$

Adequate breastfeeding is essential for the survival, health, and growth of children; it preserves the mother's health and contributes to the development of human capital. Strong evidence of this can be found in studies with humans that show the existence of a proportionally inverse relationship between the duration of breastfeeding and the risk of obesity, hypertension, dyslipidemia, and type II diabetes mellitus in adulthood. ${ }^{49}$ Based on this, since 1990, international agencies specialized in health adopted the Innocenti Declaration, recommending exclusive breastfeeding until six months of age. ${ }^{50}$ However, the WHO analyzed the duration of breastfeeding in 108 countries and found that only $32 \%$ of the children received only breast milk in the first semester of life. One of the determining factors of early weaning seems to be the socioeconomic aspect..$^{51}$ Some studies discuss that in high-income countries, the socioeconomic status seems to be positively associated with the duration of breastfeeding. Others believe that breastfeeding became less common in high-income countries during the $20^{\text {th }}$ century and that similar standards have been observed in women with a high educational level, from urban environments, and who have a higher purchasing power in middle and low-income countries. ${ }^{50,51}$ Although breastfeeding is cited as the reason for women to leave the workplace, evidence suggests that the majority remain in their jobs and choose to use breast milk substitutes or interrupt breastfeeding. ${ }^{50}$

Table 3 presents studies including animal models that evaluate the consequences of early weaning over the long term. 
Table 1 - Studies in animal models, including maternal malnutrition resulting from a lack or excess macronutrients and its outcome in offspring

\begin{tabular}{|c|c|c|c|c|}
\hline Reference & $\begin{array}{c}\text { Model of } \\
\text { malnutrition (F0 } \\
\text { generation) }\end{array}$ & Species & $\begin{array}{c}\text { Post-natal moment } \\
\text { of evaluation, } \\
\text { generation, and } \\
\text { evaluated sex }\end{array}$ & Main outcomes in the offspring \\
\hline
\end{tabular}

24

$$
\begin{aligned}
& \text { Maternal energy } \\
& \text { restriction: gestation }
\end{aligned}
$$

Wistar Rats

16 weeks (F1, F2, and

F3 generation)

Male $\uparrow$ Blood pressure

$\downarrow$ Vasodilator response to acetylcholine

Damage to the production of nitric oxide in the F1, F2, and

\begin{tabular}{|c|c|c|c|c|}
\hline 25 & $\begin{array}{l}\text { Protein restriction: } \\
\text { gestation }\end{array}$ & Wistar Rats & $\begin{array}{l}70 \text { days } \\
\text { (F1 generation) } \\
\text { Male }\end{array}$ & $\begin{array}{c}\text { Induction of cardiac fibrosis markers } \\
\text { Damage to myocardial function } \\
\downarrow \text { Ejection and shortening fractions } \\
\uparrow \text { Ventricular diameter }\end{array}$ \\
\hline 26 & $\begin{array}{l}\text { Protein restriction: } \\
\text { gestation /lactation }\end{array}$ & Wistar Rats & $\begin{array}{l}90 \text { days } \\
\text { (F1 generation) } \\
\text { Male }\end{array}$ & $\begin{array}{l}\uparrow \text { Cardiovascular sympathetic tone } \\
\uparrow \text { Blood pressure }\end{array}$ \\
\hline 27 & $\begin{array}{l}\text { Protein restriction: } \\
\text { gestation /lactation }\end{array}$ & Wistar Rats & $\begin{array}{l}\text { 70-90 days } \\
\text { (F1 generation) } \\
\text { Male }\end{array}$ & $\begin{array}{l}\text { Disruption of glutamatergic signaling in the nucleus of the } \\
\text { solitary tract } \\
\uparrow \text { Blood pressure }\end{array}$ \\
\hline 28 & $\begin{array}{c}\text { Protein restriction: } \\
\text { gestation }\end{array}$ & Albino Rats & $\begin{array}{l}24 \text { weeks } \\
\text { (F1 generation) } \\
\text { Male }\end{array}$ & $\begin{array}{l}\text { Positive regulation of nitric oxide synthase } \\
\text { Cell apoptosis } \\
\downarrow \text { Number of cardiomyocytes } \\
\uparrow \text { Interstitial Fibrosis }\end{array}$ \\
\hline 29 & $\begin{array}{l}\text { Hyperlipidic Maternal } \\
\text { Diet: gestation /lactation }\end{array}$ & $\begin{array}{c}\text { Sprague } \\
\text { Dawley Rats }\end{array}$ & $\begin{array}{l}60 \text { days } \\
\text { (F1 generation) } \\
\text { Male }\end{array}$ & $\begin{array}{c}\uparrow \text { Blood pressure } \\
\downarrow \text { Cardiac baroreflex function } \\
\uparrow \text { Response to angiotensin II and pro-inflammatory } \\
\text { cytokines through the positive regulation of the cerebral } \\
\text { renin-angiotensin system } \\
\text { Oxidative and inflammatory stress }\end{array}$ \\
\hline 30 & $\begin{array}{l}\text { Hyperlipidic Maternal } \\
\text { Diet: gestation /lactation }\end{array}$ & $\begin{array}{c}\text { Sprague } \\
\text { Dawley Rats }\end{array}$ & $\begin{array}{l}\text { Neonatal } \\
\text { (F1 generation) } \\
\text { Male and Female }\end{array}$ & $\begin{array}{c}\text { Damage in the glycolytic and respiratory capacity } \\
\uparrow \text { Lipid peroxidation and mitochondrial dysfunction } \\
\text { Cardiac dysfunction }\end{array}$ \\
\hline 31 & $\begin{array}{c}\text { Hyperlipidic Maternal } \\
\text { Diet: gestation }\end{array}$ & $\begin{array}{c}\text { Sprague } \\
\text { Dawley Rats }\end{array}$ & $\begin{array}{l}3 \text { months } \\
\text { (F1 generation) } \\
\text { Male and Female }\end{array}$ & $\begin{array}{c}\text { Gender-dependent cardiac hypertrophy } \\
\uparrow \text { Susceptibility of the heart to the ischemia/reperfusion } \\
\text { lesion in male rats } \\
\downarrow \text { Connection of the glucocorticoid receptors to their } \\
\text { response elements in the angiotensin II receptor } \\
\downarrow \text { Glucocorticoid receptors in the heart of male rats }\end{array}$ \\
\hline 32 & $\begin{array}{l}\text { Pre-gestational Maternal } \\
\text { Obesity: } \\
\text { gestation/lactation }\end{array}$ & Mice C57BL/6 & $\begin{array}{c}\text { 3, 5, 8, and } 12 \text { weeks } \\
\text { (F1 generation) } \\
\text { Male }\end{array}$ & $\begin{array}{c}\text { Cardiac hypertrophy } \\
\text { Cardiac dysfunction } \\
\text { Dominance of the sympathetic activity in the heart }\end{array}$ \\
\hline 33 & $\begin{array}{c}\text { Obesogenic Maternal } \\
\text { Diet: lactation }\end{array}$ & Mice C57BL/6 & $\begin{array}{l}8 \text { weeks } \\
\text { (F1 generation) } \\
\text { Male }\end{array}$ & $\begin{array}{c}\text { Hypertension } \\
\text { Cardiac dysfunction } \\
\text { Hypertrophy } \\
\uparrow \text { Cardiomyocyte area } \\
\text { Cardiac remodeling }\end{array}$ \\
\hline 34 & $\begin{array}{c}\text { Obesogenic Maternal } \\
\text { Diet: gestation/ lactation }\end{array}$ & $\begin{array}{c}\text { Sprague } \\
\text { Dawley Rats }\end{array}$ & $\begin{array}{l}12 \text { weeks } \\
\text { (F1 generation) } \\
\text { Male }\end{array}$ & $\begin{array}{l}\text { Modulation of the angiogenetic activity in endothelial cells } \\
\qquad \begin{array}{c}\downarrow \text { Vasorelaxant response } \\
\text { Poor revascularization } \\
\uparrow \text { Tissue fibrosis }\end{array}\end{array}$ \\
\hline
\end{tabular}

F3 generations 
Table 2 - Studies in animal models including the maternal malnutrition resulting from a lack of micronutrients and its outcome in offspring.

\begin{tabular}{|c|c|c|c|c|}
\hline Reference & $\begin{array}{l}\text { Model of malnutrition (F0 } \\
\text { generation) }\end{array}$ & Species & $\begin{array}{l}\text { Post-natal } \\
\text { moment of } \\
\text { evaluation and } \\
\text { evaluated sex (F1 } \\
\text { generation) }\end{array}$ & Main outcome in offspring \\
\hline 38 & $\begin{array}{l}\text { Maternal diet deficient in Iron: } \\
2 \text { weeks after mating and in the } \\
\text { perinatal period }\end{array}$ & $\begin{array}{c}\text { Sprague } \\
\text { Dawley Rats }\end{array}$ & $\begin{array}{l}6 \text { months } \\
\text { Male and Female }\end{array}$ & $\downarrow$ Production of nitric oxide \\
\hline 39 & $\begin{array}{l}\text { Maternal diet deficient in Zinc: } \\
\text { gestation/lactation }\end{array}$ & Wistar Rats & $\begin{array}{l}60 \text { days } \\
\text { Male }\end{array}$ & $\begin{array}{c}\uparrow \text { Blood pressure } \\
\text { Vascular dysfunction } \\
\text { Damage to the renal function }\end{array}$ \\
\hline 40 & $\begin{array}{l}\text { Maternal diet deficient in Zinc: } \\
\text { gestation/lactation }\end{array}$ & Wistar Rats & $\begin{array}{c}6 \text { and } 81 \text { days } \\
\text { Male and Female }\end{array}$ & $\begin{array}{c}\downarrow \text { Nitric oxide synthase in the aorta } \\
\uparrow \text { Oxidative stress } \\
\uparrow \text { Deposition of collagen in the tunica media } \\
\downarrow \text { Activity of endothelial nitric oxide } \\
\text { synthase } \\
\uparrow \text { Systolic blood pressure in male rats }\end{array}$ \\
\hline 41 & $\begin{array}{l}\text { Maternal diet deficient in Zinc: } \\
\text { gestation/lactation }\end{array}$ & Wistar Rats & $\begin{array}{l}81 \text { days } \\
\text { Male and Female }\end{array}$ & $\begin{array}{l}\text { Activation of apoptotic and inflammatory } \\
\qquad \text { processes } \\
\downarrow \text { Growth factor expression TGF- } \beta 1 \\
\downarrow \text { Activity of nitric oxide synthase in the } \\
\text { cardiac tissue }\end{array}$ \\
\hline 42 & $\begin{array}{c}\text { Maternal diet deficient in vitamin } \\
\text { D: } 4 \text { weeks before mating and } \\
\text { during gestation/lactation }\end{array}$ & $\begin{array}{c}\text { Sprague } \\
\text { Dawley Rats }\end{array}$ & $\begin{array}{l}3 \text { and } 30 \text { days } \\
\text { Male and Female }\end{array}$ & $\begin{array}{c}\uparrow \text { Volume of left ventricle } \\
\text { Hyperplasia and hypertrophy of } \\
\text { cardiomyocytes } \\
\uparrow \text { Proportion of mononuclear } \\
\text { cardiomyocytes }\end{array}$ \\
\hline 43 & $\begin{array}{l}\text { Maternal diet deficient in vitamin } \\
\text { D: } 6 \text { weeks before mating and } \\
\text { during gestation/lactation }\end{array}$ & $\begin{array}{c}\text { Sprague } \\
\text { Dawley Rats }\end{array}$ & $\begin{array}{l}8 \text { weeks } \\
\text { Male and Female }\end{array}$ & $\begin{array}{l}\uparrow \text { Systolic blood pressure } \\
\downarrow \text { Vascular complacency }\end{array}$ \\
\hline 44 & $\begin{array}{c}\text { Maternal diet deficient in vitamin } \\
\text { D: } 10 \text { weeks before mating and } \\
\text { during gestation }\end{array}$ & $\begin{array}{c}\text { Sprague } \\
\text { Dawley Rats }\end{array}$ & $\begin{array}{l}12 \text { weeks } \\
\text { Male and Female }\end{array}$ & $\begin{array}{l}\uparrow \text { Systolic blood pressure } \\
\text { Involvement of endothelium relaxation }\end{array}$ \\
\hline 45 & $\begin{array}{c}\text { Maternal diet deficient in Calcium: } \\
\text { gestation/lactation }\end{array}$ & Wistar Rats & $\begin{array}{l}180 \text { days } \\
\text { Male and Female }\end{array}$ & $\begin{array}{c}\uparrow \text { Serum glucose and insulin in male rats } \\
\uparrow \text { HOMA-IR Index in male rats } \\
\downarrow \text { Systolic blood pressure in female rats } \\
\downarrow \text { Heart rate in female rats }\end{array}$ \\
\hline
\end{tabular}

Functional foods and bioactive compounds: cardiometabolic reprogramming

Specialists highlight a balanced, healthy, and varied diet as the best way to prevent chronic diseases. These recommendations are based on existing associations between the consumption of foods, such as fruits, vegetables, and whole grains, and the prevention of CNCD. In fact, epidemiological studies show an inverse association between the prevalence of these diseases and the consumption of these foods. As a result, the so-called "functional foods" emerged, which provide benefits to the health of those who eat them. ${ }^{56}$

Brazilian law sets forth the legal definition of functional foods: "foods or ingredients that, in addition to their basic nutritional functions, when consumed as part of the usual diet, produce metabolic effects and/or physiological and/or benefits to health, which should be safe for consumption without medical prescription". ${ }^{57}$ These foods contain 
Table 3 - Studies in animal models including early weaning and its outcomes in offspring.

\begin{tabular}{|c|c|c|c|c|}
\hline Reference & $\begin{array}{l}\text { Protocol for early weaning (F0 } \\
\text { generation) }\end{array}$ & Species & $\begin{array}{c}\text { Post-natal } \\
\text { moment of } \\
\text { evaluation and } \\
\text { evaluated sex ( } \mathrm{F} 1 \\
\text { generation) }\end{array}$ & Main outcome in offspring \\
\hline 52 & $\begin{array}{c}\text { Physical barrier: } \\
\text { Bandages on the mother on post-natal } \\
\text { day } 18\end{array}$ & Wistar Rats & $\begin{array}{l}21 \text { and } 180 \text { days } \\
\text { Male }\end{array}$ & $\begin{array}{l}\text { Metabolic syndrome } \\
\qquad \uparrow \text { adiposity } \\
\text { dyslipidemia } \\
\text { resistence to insulin } \\
\text { resistence to leptin }\end{array}$ \\
\hline 53 & $\begin{array}{l}\text { Physical barrier: Bandages on the } \\
\text { mother or } \\
\text { pharmacological barrier: } \\
\text { administration of bromocriptine }(0.5 \\
\text { mg/kg ip twice daily) } \\
\text { on post-natal day } 18\end{array}$ & Wistar Rats & $\begin{array}{l}\text { 90, 120, } 150 \text {, and } 180 \\
\text { days } \\
\text { Male }\end{array}$ & $\begin{array}{c}\text { Hyperphagia, } \\
\uparrow \text { visceral fat and bone mass } \\
\uparrow \text { plasmatic levels of leptin and vitamin D }\end{array}$ \\
\hline 54 & $\begin{array}{l}\text { Maternal separation: } 3 \mathrm{~h} / \text { day of the } \\
\text { post-natal days } 3 \text { to } 12\end{array}$ & $\begin{array}{l}\text { Sprague } \\
\text { Dawley } \\
\text { Rats }\end{array}$ & $\begin{array}{c}\text { 55-66 days } \\
\text { Male and Female }\end{array}$ & $\begin{array}{c}\uparrow \text { cardiac response to hypoxia } \\
\text { Instability of the cardiorespiratory } \\
\text { response }\end{array}$ \\
\hline 55 & $\begin{array}{l}\text { Physical barrier: Bandages on the } \\
\text { mother or } \\
\text { pharmacological barrier: } \\
\text { administration of bromocriptine }(0.5 \\
\mathrm{mg} / \mathrm{kg} \text { ip twice daily) } \\
\text { on post-natal day } 18\end{array}$ & Wistar Rats & $\begin{array}{l}180 \text { days } \\
\text { Female }\end{array}$ & $\begin{array}{l}\text { Weight gain } \\
\uparrow \text { adiposity } \\
\text { hyperleptinemia } \\
\downarrow \text { estrogen }\end{array}$ \\
\hline
\end{tabular}

components, called "bioactive compounds", defined as "nutrients or non-nutrients normally eaten as a component of some other food, producing metabolic or physiological action in the body." 58

Studies point out that diets rich in bioactive compounds can reduce the risk of CVD. For instance, anthocyanins present in red fruits; resveratrol, phenolic compound found in grapes; catechins, found in large quantities in green tea; phytosterols, present in vegetable oils; isoflavones, found in soy beans; Omega-3 fatty acids observed in linseed, chia, and fish; probiotics present in dairy products; prebiotics found in vegetables, fruits, and whole grain, oleaginous, and leguminous cereals; among others. ${ }^{56,59-61}$ Evidence still suggests that intestinal dysbiosis plays an important role in the pathogenesis of these diseases, in which, bioactive compounds may act in the modulation of the microbiota in order to favor a healthy bacterial population..$^{61}$

The literature proposes that these compounds can unleash epigenetic changes that have accumulated throughout life, involved in the pathogenesis of diseases related to age. ${ }^{61}$ Based on DOHaD theory, it is reasonable to assume that the early life could also constitute a temporal window to begin dietetic interventions focused on the prevention of diseases. The knowledge about the consequences of the early exposure to bioactive compounds is stiil limited. Table 4 presents experimental studies that investigated whether or not these compounds would be able to prevent both the development of cardiometabolic diseases associated with malnutrition in critical periods, as well as attenuate the injuries caused by it.

\section{Epigenetics: programming and reprogramming}

As the epigenetic changes are modulated by environmental exposure, epigenetics is considered the interface between genetics and the environment. Thus, these changes have been highlighted as molecular mechanisms that are subjacent to the process that associates malnutrition in critical periods of development and cardiometabolic programming. In addition, given the capacity of response of the epigenetic markers to 
Table 4- Studies including the effects of bioactive compounds in the prevention or reprogramming of cardiometabolic diseases programmed in the offspring in different animal models of malnutrition in the beginning of life.

\begin{tabular}{|c|c|c|c|c|c|}
\hline Reference & $\begin{array}{c}\text { Model of } \\
\text { malnutrition } \\
\text { (F0 generation) }\end{array}$ & Species & $\begin{array}{c}\text { Functional } \\
\text { food/ } \\
\text { bioactive } \\
\text { compound }\end{array}$ & $\begin{array}{c}\text { Intervention: } \\
\text { F0 or F1 generation } \\
\text { Post-natal moment of } \\
\text { evaluation and evaluated } \\
\text { sex }\end{array}$ & Main outcomes in offspring \\
\hline
\end{tabular}

62

$\begin{array}{lcc}\begin{array}{c}\text { Overnutrition: } \\ \text { Reduction in }\end{array} & \text { Wistar } & \text { Yerba mate } \\ \text { the litter during } & \text { Rats } & \text { tea (Ilex } \\ \text { lactation } & & \text { paraguariensis) }\end{array}$

F1: treatment by gavage with yerba mate solution

$(1 \mathrm{~g} / \mathrm{kg} / 2 \mathrm{~mL}$ of water)

between post-natal days

150 and 180

Male
Reversion of hypothalamic resistance to insulin

Normalization of enzyme activity in the liver

$\downarrow$ Lipid peroxidation

$\downarrow$ Level of steatosis and of hepatic triglycerides

\begin{tabular}{|c|c|c|c|c|c|}
\hline 63,64 & $\begin{array}{l}\text { Early weaning: } \\
\text { physical barrier }\end{array}$ & $\begin{array}{l}\text { Wistar } \\
\text { Rats }\end{array}$ & $\begin{array}{l}\text { Calcium } \\
\text { carbonate }\end{array}$ & $\begin{array}{l}\text { F1: diet supplemented with } \\
\text { calcium carbonate }(10 \mathrm{~g} / \mathrm{kg} \\
\text { of feed) between post-natal } \\
\text { days } 120 \text { and } 180 \\
\text { Male }\end{array}$ & $\begin{array}{c}\text { Mitigated hyperphagia } \\
\downarrow \text { Overweight and adiposity } \\
\downarrow \text { Inflammatory state } \\
\downarrow \text { Resistance to vitamin D in adipocytes }\end{array}$ \\
\hline 65 & $\begin{array}{l}\text { Early weaning: } \\
\text { physical barrier }\end{array}$ & $\begin{array}{l}\text { Wistar } \\
\text { Rats }\end{array}$ & Resveratrol & $\begin{array}{c}\text { F1: treatment by gavage } \\
\text { with resveratrol solution } \\
(30 \mathrm{mg} / \mathrm{kg} \text { in a } 0.5 \% \mathrm{p} / \mathrm{v} \\
\text { solution of methylcellulose }) \\
\text { between post-natal days } 150 \\
\text { and } 180 \\
\text { Male }\end{array}$ & $\begin{array}{c}\downarrow \text { Overweight } \\
\downarrow \text { Feed intake } \\
\downarrow \text { Hypertrophia of adipocytes } \\
\downarrow \text { Serum leptin } \\
\downarrow \text { Glycemia } \\
\downarrow \text { Resistence to leptin and insulin } \\
\uparrow \text { Adiponectine }\end{array}$ \\
\hline 66 & $\begin{array}{c}\text { Hyperlipidic } \\
\text { maternal diet: } \\
\text { gestation/lactation }\end{array}$ & $\begin{array}{l}\text { Wistar } \\
\text { Rats }\end{array}$ & $\begin{array}{c}\text { Grape seed } \\
\text { extract rich in } \\
\text { Procyanidin }\end{array}$ & $\begin{array}{c}\text { F0: treatment by gavage } \\
\text { with the extract }(25 \mathrm{mg} / \mathrm{kg}) \text { : } \\
\text { gestation/lactation } \\
\text { F1: evaluated on post-natal } \\
\text { day } 30 \\
\text { Male }\end{array}$ & $\begin{array}{c}\uparrow \text { White adipose tissue } \\
\uparrow \text { Monocyte chemoattractant protein-1 } \\
\text { (MCP-1) } \\
\downarrow \text { Plasmatic levels of glycerol }\end{array}$ \\
\hline 67 & $\begin{array}{c}\text { Hyperlipidic } \\
\text { maternal diet: } \\
\text { lactation }\end{array}$ & $\begin{array}{l}\text { Wistar } \\
\text { Rats }\end{array}$ & $\begin{array}{l}\text { Grape skin } \\
\text { extract (Vitis } \\
\text { vinifera } L .)\end{array}$ & $\begin{array}{c}\text { F0: treatment by gavage } \\
\text { with the extract }(200 \mathrm{mg} / \mathrm{kg}) \text { : } \\
\text { lactation } \\
\text { F1: evaluated on post-natal } \\
\text { days } 90 \text { and } 150 \\
\text { Male }\end{array}$ & $\begin{array}{c}\text { Reversion of resistance to insulin } \\
\downarrow \text { Systolic blood pressure } \\
\downarrow \text { Adiposity } \\
\downarrow \text { Plasmatic triglycerides } \\
\downarrow \text { Glycemia } \\
\downarrow \text { Oxidative stress }\end{array}$ \\
\hline 68 & $\begin{array}{l}\text { Maternal diabetes } \\
\text { induced by diet or } \\
\text { administration of } \\
\text { streptozocine } \\
(35 \mathrm{mg} / \mathrm{kg})\end{array}$ & $\begin{array}{l}\text { Wistar } \\
\text { Rats }\end{array}$ & $\begin{array}{l}\text { Linseed flour } \\
\text { and oil }\end{array}$ & $\begin{array}{c}\text { F0: feed supplemented } \\
\text { with linseed flour ( } 25 \%) \text { or } \\
\text { linseed oil }(7 \%) \text { : gestation/ } \\
\text { lactation } \\
\text { F1: evaluated on post-natal } \\
\text { day } 100 \\
\text { Male }\end{array}$ & $\begin{array}{c}\text { Unaltered biochemical parameters } \\
\text { Hindered aortic remodeling }\end{array}$ \\
\hline
\end{tabular}




\begin{tabular}{|c|c|c|c|c|c|}
\hline 69 & $\begin{array}{c}\text { Maternal } \\
\text { hyperlipidic } \\
\text { diet: gestation/ } \\
\text { lactation }\end{array}$ & $\begin{array}{l}\text { Sprague } \\
\text { Dawley }\end{array}$ & $\begin{array}{l}\text { Prebiotic: } \\
\text { Long chain } \\
\text { inulin or } \\
\text { Probiotic: } \\
\text { Lactobacillus } \\
\text { casei }\end{array}$ & $\begin{array}{c}\text { F0: treatment with Inulin } \\
(5 \% \mathrm{p} / \mathrm{p}) \text { or Lactobacillus } \\
\text { casei }(2 \times 108 \mathrm{UFC} / \text { day }), \\
\text { concomitant to hyperlipidic } \\
\text { diet } \\
\text { F1: evaluated after } 16 \text { weeks } \\
\text { Male }\end{array}$ & $\begin{array}{l}\text { Hindered increase in blood pressure } \\
\qquad \uparrow \text { Beneficial bacteria }\end{array}$ \\
\hline 70 & $\begin{array}{l}\text { Maternal diet } \\
\text { with high fructose } \\
\text { content }(60 \%): \\
\text { gestation/lactation }\end{array}$ & $\begin{array}{l}\text { Sprague } \\
\text { Dawley }\end{array}$ & Resveratrol & $\begin{array}{c}\text { F1: diet similar to maternal } \\
+ \text { resveratrol }(50 \mathrm{mg} / \mathrm{L}) \text { until } \\
\text { post-natal day } 90 \\
\text { Male }\end{array}$ & $\begin{array}{c}\downarrow \text { Blood pressure } \\
\downarrow \text { Renal oxidative stress } \\
\text { Positive modulation of the intestinal } \\
\text { microbiota }\end{array}$ \\
\hline 71 & $\begin{array}{l}\text { Supplementation } \\
\text { of fructose in } \\
\text { the mother's } \\
\text { water }(100 \mathrm{~g} / \mathrm{L}) \text { : } \\
\text { gestation }\end{array}$ & $\begin{array}{l}\text { Wistar } \\
\text { Rats }\end{array}$ & $\begin{array}{l}\text { Melinjo } \\
\text { seed extract } \\
\text { (Gnetum } \\
\text { gnemon) }\end{array}$ & $\begin{array}{l}\text { F0: diet supplemented with } \\
\text { 0.1\% Melinjo: lactation } \\
\text { F1: evaluated in day } 17 \text { after } \\
\text { weaning } \\
\text { Female }\end{array}$ & $\begin{array}{c}\uparrow \text { Protein kinase expression activated } \\
\text { by phosphorylated adenosine } \\
\text { monophosphato (AMPK) and of } \\
\text { endothelial nitric oxide synthase in the } \\
\text { kidneys } \\
\downarrow \text { Systolic blood pressure }\end{array}$ \\
\hline 72 & $\begin{array}{l}\text { Maternal } \\
\text { hypoprotein diet: } \\
\text { gestation }\end{array}$ & $\begin{array}{l}\text { Wistar } \\
\text { Rats }\end{array}$ & $\begin{array}{c}\text { Green tea } \\
\text { extract }\end{array}$ & $\begin{array}{l}\text { F0: diet supplemented with } \\
0.12 \% \text { or } 0.24 \% \text { of green tea } \\
\text { extract: lactation } \\
\text { F1: evaluated after weaning } \\
\text { Female }\end{array}$ & $\begin{array}{c}\text { Higher dose of green tea extract: } \\
\downarrow \text { Infiltration of macrophages and areas } \\
\text { of fibrosis in the cardiac tissue } \\
\text { Restored the serum concentration of } \\
\text { insulin }\end{array}$ \\
\hline 73 & $\begin{array}{l}\text { Maternal } \\
\text { hypoprotein diet: } \\
\text { gestation. }\end{array}$ & $\begin{array}{l}\text { Wistar } \\
\text { Rats }\end{array}$ & $\begin{array}{l}\text { Adzuki } \\
\text { beans (Vigna } \\
\text { angularis) }\end{array}$ & $\begin{array}{l}\text { F0: received a normoprotein } \\
\text { diet supplemented with } \\
\text { Adzuki beans: lactation } \\
\text { F1: evaluated at } 3 \text { and } 23 \\
\text { weeks of age } \\
\text { Male }\end{array}$ & $\begin{array}{l}\downarrow \text { Body weight } \\
\downarrow \text { Hepatic levels of triglycerides } \\
\uparrow \text { Phosphorylation of AMPK (liver and } \\
\text { skeletal muscle) and Acetyl coenzyme } \\
\text { Carboxylase (skeletal muscle). }\end{array}$ \\
\hline
\end{tabular}

food factors, one can speak of "epigenetic foods", a type of functional food containing bioactive compounds capable of modulating the microRNA expression, DNA methylation, or histone modifications. ${ }^{74}$

Epigenetic modifications have been observed in cardiac pathologies. Analyses of newborns mice or healthy and heart failure (HF) adult mice cardiomyocytes DNA, showed an important role in DNA methylation in the modulation of many aspects of the cardiac biology, including in the development of the disease. ${ }^{75}$ By contrast, the role of histones in the cardiovascular biology, as well as the role of histone deacetylase (HDAC) enzymes, as therapeutic targets of heart diseases, has been well defined. ${ }^{76}$ Treatment using an in vivo HDAC inhibitor attenuated the cardiac hypertrophy and fibrosis ${ }^{77}$ in hearts of rodents exposed to hypertrophic stimuli. Moreover, the microRNAs can regulate multiple cell functions involved in atherosclerosis, such as oxidative stress, cholesterol metabolism, and endothelial dysfunction. ${ }^{78}$

Analyses of DNA methylation in the entire genome of siblings of the same sex in the cohort of the Dutch Famine study revealed a pattern of differentially methylated regions, associated with malnutrition. ${ }^{79}$ Experimental studies that analyzed offsprings of mothers submitted to protein restrictions during gestation observed a reduction in the supply of methyl groups stemming from glycine, hypomethylation of the hepatic receptor of the glucocorticoids, altered histone methylation, and an increase in the DNA methylation in hepatocytes. ${ }^{21}$ Consistent with these findings, the mother's energy restriction during gestation led to DNA hypomethylation in the hepatic tissue of the offspring, resulting in an increase in the gene expression involved in the oxidation of fatty acids and the reduction of genes involved in the lipid 
synthesis. ${ }^{21}$ By contrast, the excessive consumption of carbohydrates by the mother during gestation changes the DNA methylation, leading to changes in the gene expression responsible for adipogenesis in the white adipose tissue, in turn programming obesity in the offspring. ${ }^{21}$ Finally, Strakovsky et al. ${ }^{80}$ showed that, upon modifying the histone acetylation, a maternal hyperlipidic diet contributed to changing the expression of antioxidant enzymes in newborns.

Many micronutrients are essential for a wide range of metabolic processes, including methylation and transamination reactions ${ }^{81}$ These processes involve many enzymes with methyltransferase activity, in addition to co-factors, such as choline, methionine, zinc, and vitamins B6, B12, and B9, acting as methyl donors. B9 is a donor of one-carbon for DNA methylation and synthesis; its role is crucial during the early post-natal development, when rapid growth and cell proliferation take place. The B12 deficiency can result in global hypomethylation, since, together with the B9, it is involved in methionine synthesis and S-adenosil methionine, necessary donors for the maintenance of DNA methylation patterns. ${ }^{81,82}$ Due to its role in DNA methylation, zinc can exert a key influence upon the epigenome. Its deficiency during the intrauterine and post-natal life can contribute to change the methylation processes, which can lead to the development of chronic diseases and increase cardiovascular risks. ${ }^{82}$

There is evidence that sustains the notion that breast milk influences the DNA methylation and that this food contains microRNAs involved in the regulation of the gene expression at the post-transcriptional level. This study raised the hypothesis that the microbioma mediates the effects of this compound in this process, given that breastfeeding can modulate the composition of the intestinal microbiota and that this influences the DNA methylation. ${ }^{83}$ One study, which compared rats submitted to early weaning, who were fed a formula rich in carbohydrates, and rats fed only with breast milk, showed lower levels of mRNA of the Nyp gene (which codifies the $Y$ neuropeptide - orexigenic peptide) and of histone acetylation, as well as higher levels of mRNA of the Pomc gene (anorexigenic peptide) in the rats that received breast milk, possibly associated with high levels of histone acetylation in this group. Both of the genes are involved in many physiological processes, mainly energy homeostasis. ${ }^{83}$
As regards the bioactive compounds, in vitro and in vivo studies have demonstrated that these perform their protector effects in the chronic diseases by means of different mechanisms involving nutrigenomics. Anthocyanins have been associated with histone modifications, DNA methylation, and microRNA expression. Other bioactive compounds, such as isoflavones, curcumin, and resveratrol can regulate the activity of HDAC enzymes and histone acetyltransferase (HAT) and, consequently, modulate the histone acetylation. The benefits to one's health are attributed to these epigenetic mechanisms. ${ }^{15,61}$

DNA methylation has also been associated with the catechins present in green tea. The epigallocatechin-3gallate (EGCG) can inhibit the DNMT enzyme (DNA methyltransferase) through indirect mechanisms or through the reduction of its expression, in addition to modulating epigenetic processes at the level of histone modifications. Moreover, studies have also suggested that butyrate, a short chain fatty acid formed in the colon through prebiotic fermentation by bacteria, seems to inhibit the HDAC activity, corroborating with a possible interaction between the epigenome and the microbioma. ${ }^{15,61}$

\section{Discussion}

The DOHaD theory search to fill in the blanks in the knowledge of how nutritional experiences in crucial stages of early life can impact one's health in the long term. ${ }^{6,10}$ Both, programming and reprogramming of diseases, seem to occur through epigenetic mechanisms that show how the nutritional environment, whether adequate or not, can affect the functioning of genes, influencing the phenotype ${ }^{15}$ However, epidemiological studies in involving human beings present some limitations that make a definitive conclusion difficult, not only due to the long interval of time between the cause (malnutrition in early life) and the effect (CVD in adulthood), but also due to the difficulty to obtain precise nutritional data in both qualitative and quantitative terms. These questions highlight the relevance of studies including animal models, especially small animals, such as rodents, which have a short lifecycle, which in turn makes the control of nutritional aspects feasible. ${ }^{7,84}$ Even including distinct species, with different body sizes in the maturity rate and in other life history aspects, the literature suggests that the use of animal models 
in studies involving development plasticity are appropriate for the study of similar effects in humans, though the strength of this association can vary with the study's design, ${ }^{85}$ corroborating the relevance of studies with a translational approach.

Studies have demonstrated that, in addition to the adaption of energy and micro-macronutrients in one's diet, bioactive compounds also modulate effectors of the cardioprotector genes. Nevertheless, one major challenge includes a better definition of the regulator adaptive aspects of the cardiac epigenome, considering various feeding patterns in a complete meal. Trials that evaluate the conventional consumption of foods are different from those that involve pharmacos and present innumerous variables, including not only the adhesion to the diet, but also the lifestyle, the nutrient-nutrient, pharmaco-nutrient, or comorbidity-nutrient interactions. The challenge in terms of food components, concentrations, processing, solubility in water/lipids and stability, bioconversion, metabolytes, interactions, and time of ingestion, focused on the variety of epigenetic agents, requires a detailed evaluation in the context of cardiovascular health. Circulating epigenetic markers do not always reflect epigenetic effects of diet at the tissue/cell level in healthy individuals and patients in different stages of the disease. Tools involving sequencing and bioinformatics, for example, can minimize the limitations of these studies in defining the cause-effect relationships and the composition of ingredients, as well as the level of ideal intake. Despite the scarcity of beneficial results from clinical trials, approaches based on health teams can be useful for the comprehension of the interindividual response to a cardioprotector diet in the presence of common genetic variants and a similar microenvironment, as well as its point of intersection with the epigenome, to personalize the results. ${ }^{86}$

\section{Final considerations}

The development of public policies that favor the adequate nutrition of mothers in gestational and breastfeeding periods, as well as exclusive breastfeeding up to six months of age, seem to constitute important strategies to reduce the incidence of cardiometabolic diseases in the population, diminishing direct and indirect expenses in health care.
Although it is challenging to obtain consistent findings in clinical studies with bioactive compounds, the introduction of functional foods in one's diet can constitute an additional strategy to mitigate the deleterious effects observed in the long run, resulting from malnutrition in early life. Epigenetic mechanisms, which can be gender dependent, represent the key to developmental plasticity and are involved in both programming and reprogramming of the cardiovascular system.

\section{Author contributions}

Conception and design of the research: Marques EB, Scaramello CVB. Acquisition of data: Marques EB, de Souza KP, Alvim-Silva T, Martins ILF, Pedro SS, Scaramello CVB. Analysis and interpretation of the data: Marques EB, de Souza KP, Alvim-Silva T, Martins ILF, Pedro SS, Scaramello CVB. Obtaining financing: Scaramello CVB. Writing of the manuscript: Marques EB, de Souza KP, Alvim-Silva T, Martins ILF, Pedro SS, Scaramello CVB. Critical revision of the manuscript for intellectual content: Marques EB, de Souza KP, Alvim-Silva T, Scaramello CVB.

\section{Potential Conflict of Interest}

No potential conflict of interest relevant to this article was reported.

\section{Sources of Funding}

This study received funding from Fundação de Amparo à Pesquisa do Estado do Rio de Janeiro (FAPERJ), Conselho Nacional de Desenvolvimento Científico e Tecnológico (CNPq), and Coordenação de Aperfeiçoamento de Pessoal de Nível Superior (CAPES) - Financial Code 001.

\section{Study Association}

This study is not associated with any thesis or dissertation work.

\section{Ethics approval and consent to participate}

This article does not contain any studies with human participants or animals performed by any of the authors. 


\section{References}

1. WHO (2016). World Health Organization. Cardiovascular Diseases (CVDs). [Cited in 2020 Jan 15] Available from:<http://www.who.int/ mediacentre/factsheets/fs317/en/index.html>.

2. GBD 2016 Brazil Collaborators. Burden of disease in Brazil, 1990-2016: a systematic subnational analysis for the Global Burden of Disease Study 2016. Lancet. 2018; 392(10149):760-75.

3. Siqueira ASE, Siqueira Filho AG, Land MGP. Análise do Impacto Econômico das Doenças Cardiovasculares nos Últimos Cinco Anos no Brasil. Arq Bras Cardiol. 2017; 109(1):39-46.

4. Crispi F, Crovetto F, Gratacos E. Intrauterine growth restriction and later cardiovascular function. Early Hum Dev. 2018;126:23-27.

5. Barker DJ, Eriksson JG, Forsén T, Osmond C. Fetal origins of adult disease: strength of effects and biological basis. Int J Epidemiol. 2002;31(6):1235-39.

6. Mathias PCF, Elmhiri G, Oliveira JC, Delayre-Orthez C, Barella LF, Tófolo LP, et al. Maternal diet, bioactive molecules, and exercising as reprogramming tools of metabolic programming. Eur J Nutr. 2014;53:71122

7. Langley-Evans SC. Nutrition in early life and the programming of adult disease: a review. J Hum Nutr Diet. 2015;28 (Suppl 1):1-14.

8. Senyo SE, Lee RT, Kühn B. Cardiac regeneration based on mechanisms of cardiomyocyte proliferation and differentiation. Stem Cell Res. 2014;13(3 Pt B):532-41.

9. Zebrowski DC, Jensen CH, Becker R, Ferrazzi F, Baun C, Hvidsten S, et al. Cardiac injury of the newborn mammalian heart accelerates cardiomyocyte terminal differentiation. Sci Rep. 2017;7(1):8362.

10. Reynolds CM, Gray C, Li M, Segovia SA, Vickers MH. Early Life Nutrition and Energy Balance Disorders in Offspring in Later Life. Nutrients. 2015; 7(9):8090-111.

11. Wells JC. The thrifty phenotype: An adaptation in growth or metabolism? Am J Hum Biol. 2011;23(1):65-75.

12. Tiffon C. The Impact of Nutrition and Environmental Epigenetics on Human Health and Disease. Int J Mol Sci. 2018;19(11).pii: E3425.

13. Ordovás JM, Smith CE. Epigenetics and cardiovascular disease. Nat Rev Cardiol. 2010;7(9):510-9.

14. Vickers MH. Developmental programming of the metabolic syndromecritical windows for intervention. World J Diabetes. 2011;2(9):137-48.

15. Silva LBAR, Pinheiro-Castro N, Novaes GM, Pascoal GFL, Ong TP. Bioactive food compounds, epigenetics and chronic disease prevention: Focus on early-life interventions with polyphenols. Food Res Int. 2019;125:108646.

16. Baggio G, Corsini A, Floreani A, Giannini S, Zagonel V. Gender medicine: a task for the third millennium. Clin Chem Lab Med. 2013;51(4):713-27.

17. Woodman AG, Noble RMN, Panahi S, Gragasin FS, Bourque SL. Perinatal iron deficiency combined with a high salt diet in adulthood causes sexdependent vascular dysfunction in rats. J Physiol. 2019; 597(18):4715-28.

18. Ponzio BF, Carvalho MH, Fortes ZB, Franco MC. Implications of maternal nutrient restriction in transgenerational programming of hypertension and endothelial dysfunction across F1-F3 offspring. Life Sci. 2012; 90(1516):571-7.

19. Thurner S, Klimek P, Szell M, Duftschmid G, Endel G, Kautzky-Willer A, et al. Quantification of excess risk for diabetes for those born in times of hunger, in an entire population of a nation, across a century. Proc Natl Acad Sci USA. 2013;110(12):4703-7.

20. World Health Organization.(WHO).2018 Malnutrition. [Cited in 2020 Jan 26] Available from: https://www.who.int/news-room/fact-sheets/detail/ malnutrition>. Acesso em 26 de janeiro de 2020.

21. Kereliuk SM, Brawerman GM, Dolinsky VW. Maternal Macronutrient Consumption and the Developmental Origins of Metabolic Disease in the Offspring. Int J Mol Sci. 2017;18(7), pii: E1451.
22. Siddeek B, Mauduit C, Yzydorczyk C, Benahmed M, Simeoni U. At the heart of programming: the role of micro-RNAs. J Dev Orig Health Dis. 2018;9(6):615-31.

23. Heidari-Beni M. Early life Nutrition and Non-Communicable Disease. Adv Exp Med Biol. 2019;1121:33-40.

24. Ponzio BF, Carvalho MH, Fortes ZB, Franco MC. Implications of materna nutrient restriction in transgenerational programming of hypertension and endothelial dysfunction across F1-F3 offspring. Life Sci. 2012; 90(1516):571-7.

25. Menendez-Castro C, Toka O, Fahlbusch F, Cordasic N, Wachtveitl $\mathrm{R}$, Hilgers KF, et al. Impaired myocardial performance in a normotensive rat model of intrauterine growth restriction. International Pediatric Research Foundation. 2014;75(6):697-706

26. Barros MA, De Brito Alves JL, Nogueira VO, Wanderley AG, Costa-Silva JH. Maternal low-protein diet induces changes in the cardiovascular autonomic modulation in male rat offspring. Nutr Metab Cardiovasc Dis. 2015;25(1):123-30.

27. Alves DS, Barbosa DFS, Nogueira VO, Tourneur Y, Fontes DAF, BritoAlves JL, et al. Maternal protein restriction affects cardiovascular, but not respiratory response to L-glutamate microinjection into the NTS of conscious rats. Nutr Neurosci. 2019:1-12.

28. Amer MG, Mohamed NM, Shaalan AAM. Gestational protein restriction: study of the probable effects on cardiac muscle structure and function in adult rats. Histol Histopathol. 2017;32(12):1293-303.

29. Zhang YP, Yan-Li Huo YL, Fang ZQ, Wang XF, Li JD, Wang HP et. al. Maternal high-fat diet acts on the brain to induce baroreflex dysfunction and sensitization of angiotensin II-induced hypertension in adult offspring. Am J Physiol Heart Circ Physiol. 2018;314(5):1061-69.

30. Mdaki KS, Larsen TD, Wachal AL, Schimelpfenig MD, Weaver LJ, Dooyema SDR et al. Maternal high-fat diet impairs cardiac function in offspring of diabetic pregnancy through metabolic stress and mitochondrial dysfunction. Am J Physiol Heart Circ Physiol. 2016;310(6):681-92

31. Xue Q, Chen P, Li X, Zhang G, Patterson AJ, Luo J. Maternal High-Fat Diet Causes a Sex-Dependent Increase in AGTR2 Expression and Cardiac Dysfunction in Adult Male Rat Offspring. Biol Reprod. 2015;93(2):49.

32. Blackmore HL, Niu Y, Fernandez-Twinn DS, Tarry-Adkins JL, Giussani DA, Ozanne SE. Maternal Diet-induced Obesity Programs Cardiovascular Dysfunction in Adult Male Mouse Offspring Independent of Current Body Weight. Endocrinology. 2014;155(10):3970-80.

33. Loche E, Blackmore HL, Carpenter AA, Beeson JH, Pinnock A, Ashmore TJ, et al. Maternal diet-induced obesity programmes cardiac dysfunction in male mice independently of post-weaning diet. Cardiovasc Res. 2018;114(10):1372-84

34. Leu S, Wu KLH, Lee WC, Tain YL, Chan JYH. The impact of maternal fructose exposure on angiogenic activity of endothelial progenitor cells and blood flow recovery after critical limb ischemia in rat offspring. Int J Mol Sci. 2019; 20(10):1-20.

35. Gernand AD, Schulze KJ, Stewart CP, West KP, Christian P. Micronutrient deficiencies in pregnancy worldwide: health effects and prevention. Nat Rev Endocrinol. 2016;12(5):274-89.

36. Aguirre S, Veiras LC, Sánchez R, Alcalde DLC, Elesgaray R, Costa MA et al. Fetal Programming of Hypertension Induced by Moderate Zinc Restriction during Prenatal Life and Lactation: Early Morphological and Functional Alterations in Cardiovascular System in Both Sexes. Rev Argent Cardiol. 2011;79:322-28.

37. Amoroso L. The Second International Conference on Nutrition: implications for hidden hunger. World Rev Nutr Diet. 2016; 115:142-52.

38. Woodman AG, Noble RMN, Panahi S, Gragasin FS, Bourque SL. Perinatal iron deficiency combined with a high salt diet in adulthood causes sexdependent vascular dysfunction in rats. J Physiol. 2019; 597(18):4715-28. 
39. Tomat A, Elesgaray R, Zago V, Fasoli H, Fellet A, Balaszczuk AM, et al. Exposure to zinc deficiency in fetal and postnatal life determines nitric oxide system activity and arterial blood pressure levels in adult rats. British Journal of Nutrition. 2010;104:382-9.

40. Abregú FMG, Gobetto MN, Juriol LV, Caniffi C, Elesgaray R, Tomat $\mathrm{AL}$, et al. Developmental programming of vascular dysfunction by prenatal and postnatal zinc deficiency in male and female rats. Journal of Nutritional Biochemistry. 2018;56:89-98.

41. Juriol LV, Gobetto MN, Abregú FMG, Dasso ME, Pineda G, Güttlein $\mathrm{L}$, et al. Cardiac changes in apoptosis, inflammation, oxidative stress, and nitric oxide system induced by prenatal and postnatal zinc deficiency in male and female rats. Eur J Nutr. 2018;57:569-83.

42. Gezmish O, Tare M, Parkington HC, Morley R, Porrello ER, Bubb KJ, et al. Maternal Vitamin D Deficiency Leads to Cardiac Hypertrophy in Rat Offspring. Reproductive Sciences. 2010;17(2):168-76.

43. Tare M, Emmett SJ, Coleman HA, Skordilis C, Eyles DW, Morley R, et al. Vitamin D insufficiency is associated with impaired vascular endothelial and smooth muscle function and hypertension in young rats. J Physiol. 2011; 589(Pt 19):4777-86.

44. Meems LMG, Mahmud H, Buikema H, Tost J, Michel S, Takens J, et al. Parental vitamin D deficiency during pregnancy is associated with increased blood pressure in offspring via Panx1 hypermethylation. Am J Physiol Heart Circ Physiol. 2016;311: H1459-H1469.

45. Takaya J, Yamanouchi S, Kino J, Tanabe Y, Kaneko K. A CalciumDeficient Diet in Dams during Gestation Increases Insulin Resistance in Male Offspring. Nutrients. 2018;10(11):pii: E1745.

46. Boquien CY. Human Milk: An Ideal Food for Nutrition of Preterm Newborn. Front Pediatr. 2018;6:295.

47. Martin CR, Ling P, Blackburn GL. Review of Infant Feeding: Key Features of Breast Milk and Infant Formula. Nutrients. 2016;8:279.

48. Ballard A, Morrow AL. Human milk composition: nutrients and bioactive factors. Pediatr Clin North Am. 2013;60(1):49-74.

49. Kelishadi R, Farajian S. The protective effects of breastfeeding on chronic non-communicable diseases in adulthood: A review of evidence. Adv Biomed Res. 2014;3:3.

50. Rollins NC, Bhandari N, Hajeebhoy N, Horton S, Lutter CK, Martines JC, et al. Lancet Breastfeeding Series Group. Why invest, and what it will take to improve breastfeeding practices? Lancet. 2016;387(10017):491-504.

51. Maciel BLL, Moraes ML, Soares AM, Cruz IFS, de Andrade MIR, Filho JQ, et al. Infant feeding practices and determinant variables for early complementary feeding in the first 8 months of life: results from the Brazilian MAL-ED cohort site. Public Health Nutr. 2018; 21(13):2462-70.

52. Lima NS, Moura EG, Passos MC, Neto JF, Reis AM, Oliveira E et al. Early weaning causes undernutrition for a short period and programmes some metabolic syndrome components and leptin resistance in adult rat offspring. Br J Nutr. 2011;105(9):1405-13.

53. Maia LA, Lisboa PC, Oliveira E, Lima NS, Lima ICB, Lopes RT, et al. Bone metabolism in obese rats programmed by early weaning. Metabolism. 2014; 63(3):352-64.

54. Soliz J, Tam R, Kinkead R. Neonatal Maternal Separation Augments Carotid Body Response to Hypoxia in Adult Males but Not Female Rats. Front Physiol. 2016;7:43.

55. Pietrobon CB, Bertasso IM, Silva BS, Peixoto-Silva N, Oliveira E, Moura EG, et al. Body Adiposity and Endocrine Profile of Female Wistar Rats of Distinct Ages that were Early Weaned. Horm Metab Res. 2020; 52(1):58-66.

56. Mulero J, Abellán J, Zafrilla P, Amores D, Hernández Sánchez P. Bioactive substances with preventive effect in cardiovascular diseases. Nutr Hosp. 2015; 32(4):1462-7.
57. Brasil.Ministério da Saúde. ANVISA - Agência Nacional de Vigilância Sanitária. Aprova o regulamento técnico que estabelece as diretrizes básicas para análise e comprovação de propriedades funcionais e ou de saúde alegadas em rotulagem de alimentos. Resolução n. 18, de 3 de dezembro de 1999. [Citado em 26 jan 2020] Disponível em: < http:// portal.anvisa.gov.br/documents/33916/388845/RESOLUCAO_18_1999. pdf/d2c5f6d0-f87f-4bb6-a65f-8e63d3dedc61>.

58. Brasil.Ministério da Saúde. ANVISA - Agência Nacional de Vigilância Sanitária. Aprova o Regulamento Técnico de Substâncias Bioativas e Probióticos Isolados com Alegação de Propriedades Funcional e ou de Saúde. Resolução RDC n 2, de 07 de janeiro de 2002. [Citado em 26 jan 2020]. Disponível em: <http://portal.anvisa.gov.br/ documents/10181/2718376/RDC_02_2002_COMP.pdf/68a25113-35e24327-a75f-ae22e714ca7c>.

59. Hunter PM, Hegele RA. Functional foods and dietary supplements for the management of dyslipidaemia. Nat Rev Endocrinol. 2017;13(5):278-88.

60. Plumb J, Pigat S, Bompola F, Cushen M, Pinchen H, Nørby E, et al. eBASIS (Bioactive Substances in Food Information Systems) and Bioactive Intakes: Major Updates of the Bioactive Compound Composition and Beneficial Bioeffects Database and the Development of a Probabilistic Model to Assess Intakes in Europe. Nutrients. 2017; 9(4).pii: E320.

61. Vahid F, Zand H, Nosrat-Mirshekarlou E, Najafi R, Hekmatdoost A. The role dietary of bioactive compounds on the regulation of histone acetylases and deacetylases: a review. Gene. 2015;562(1):8-15.

62. Conceição EP, Kaezer AR, Peixoto-Silva N, Felzenszwalb I, de Oliveira E, Moura EG, et al. Effects of Ilex paraguariensis (yerba mate) on the hypothalamic signaling of insulin and leptin and liver dysfunction in adult rats overfed during lactation. J Dev Orig Health Dis. 2017;8(1):123-32.

63. Nobre JL, Lisboa PC, Lima Nda S, Franco JG, Nogueira Neto JF, de Moura EG, et al. Calcium supplementation prevents obesity, hyperleptinaemia and hyperglycaemia in adult rats programmed by early weaning. $\mathrm{Br} \mathrm{J}$ Nutr. 2012; 107(7):979-88

64. Nobre JL, Lisboa PC, Peixoto-Silva N, Quitete FT, Carvalho JC, de Moura EG, et al. Role of vitamin D in adipose tissue in obese rats programmed by early weaning and post diet calcium. Mol. Nutr. Food Res. 2016;60:810-22.

65. Franco JG, Lisboa PC, da Silva Lima N, Peixoto-Silva N, Maia LA, Oliveira E, et al. Resveratrol prevents hyperleptinemia and central leptin resistance in adult rats programmed by early weaning. Horm Metab Res. $2014 ; 46(10): 728-35$

66. Del Bas JM, Crescenti A, Arola-Arnal A, Oms-Oliu G, Arola L, Caimari A. Grape seed procyanidin supplementation to rats fed a high-fat diet during pregnancy and lactation increases the body fat content and modulates the inflammatory response and the adipose tissue metabolism of the male offspring in youth. Int J Obes (Lond). 2015;39(1):7-15.

67. Resende AC, Emiliano AF, Cordeiro VS, de Bem GF, de Cavalho LC, de Oliveira PR, et al. Grape skin extract protects against programmed changes in the adult rat offspring caused by maternal high-fat diet during lactation. J Nutr Biochem. 2013; 24(12):2119-26.

68. Vicente GC, Correia-Santos AM, Suzuki A, Velarde LG, Chagas MA, Boaventura GT. Maternal exposure to diets containing flaxseed flour or flaxseed oil during pregnancy and lactation protects the aortic remodeling in adult male offspring of diabetic rat dams. J Sci Food Agric. 2015;95(14):2973-80.

69. Hsu CN, Hou CY, Chan JYH, Lee CT, Tain YL. Hypertension Programmed by Perinatal High-Fat Diet: Effect of Maternal Gut Microbiota-Targeted Therapy. Nutrients. 2019;11(12).pii: E2908.

70. Tain YL, Lee WC, Wu KLH, Leu S, Chan JYH. Resveratrol Prevents the Development of Hypertension Programmed by Maternal Plus PostWeaning High-Fructose Consumption through Modulation of Oxidative Stress, Nutrient-Sensing Signals, and Gut Microbiota. Mol Nutr Food Res. 2018:e1800066. 
71. Uson-Lopez RA, Kataoka S, Mukai Y, Sato S, Kurasaki M. Melinjo (Gnetum gnemon) Seed Extract Consumption during Lactation Improved Vasodilation and Attenuated the Development of Hypertension in Female Offspring of Fructose-Fed Pregnant Rats. Birth Defects Res. 2018;110(1):27-34

72. Matsumoto E, Kataoka S, Mukai Y, Sato M, Sato S. Green tea extract intake during lactation modified cardiac macrophage infiltration and AMP-activated protein kinase phosphorylation in weanling rats from undernourished mother during gestation and lactation. J Dev Orig Health Dis. 2017;8(2):178-87.

73. Mukai Y, Sun Y, Sato S. Azuki bean polyphenols intake during lactation upregulate AMPK in male rat offspring exposed to fetal malnutrition. Nutrition. 2013;29(1):291-7.

74. Milagro FI, Mansego ML, DeMiguel C, Martínez JA. Dietary factors, epigenetic modifications and obesity outcomes: progresses and perspectives. Mol Aspects Med. 2013;34(4):782-812

75. Gilsbach R, Preissl S, Grüning BA, Schnick T, Burger L, Benes V, et al. Dynamic DNA methylation orchestrates cardiomyocyte development, maturation and disease. Nat Commun. 2014; 5:5288.

76. Tingare A, Thienpont B, Roderick HL. Epigenetics in the heart: the role of histone modifications in cardiac remodeling. Biochem Soc Trans. 2013; 41(3):789-96.

77. Iyer A, Fenning A, Lim J, Le GT, Reid RC, Halili MA, et al. Antifibrotic activity of an inhibitor of histone deacetylases in DOCA-salt hypertensive rats. $\mathrm{Br} J$ Pharmacol. 2010;159(7):1408-17.

78. Schober A, Weber C. Mechanisms of MicroRNAs in Atherosclerosis. Annu Rev Pathol. 2016;11:583-616.
79. Tobi EW, Goeman JJ, Monajemi R, Gu H, Putter H, Zhang Y, et al. DNA methylation signatures link prenatal famine exposure to growth and metabolism. Version 2. Nat Commun. 2014;5:5592.

80. Strakovsky RS, Zhang X, Zhou D, Pan Y-X. The regulation of hepatic Pon1 by a maternal high-fat diet is gender specific and may occur through promoter histone modifications in neonatal rats. J Nutr Biochem. 2014;25:170-6.

81. Skjærven KH, Jakt LM, Fernandes JMO, Dahl JA, Adam AC, Klughammer J, et al. Parental micronutrient deficiency distorts liver DNA methylation and expression of lipid genes associated with a fatty-liver-like phenotype in offspring. Sci Rep. 2018;8(1):3055

82. Indrio F, Martini S, Francavilla R, Corvaglia L, Cristofori F, Mastrolia SA, et al. Epigenetic Matters: The Link between Early Nutrition, Microbiome, and Long-term Health Development. Front Pediatr. 2017;5:178.

83. Hartwig FP, Loret de Mola C, Davies NM, Victora CG, Relton CL. Breastfeeding effects on DNA methylation in the offspring: A systematic literature review. PLoS One. 2017;12(3):e0173070.

84. Grandjean AC. Dietary intake data collection: challenges and limitations. Nutr Rev. 2012;70 ( Suppl 2):S101-S104.

85. Thayer ZM, Wilson MA, Kim AW, Jaeggi AV. Impact of prenatal stress on offspring glucocorticoid levels: A phylogenetic meta-analysis across 14 vertebrate species. Sci Rep. 2018;8(1):4942.

86. Lionetti V, Tuana BS, Casieri V, Parikh M, Pierce GN. Importance of functional food compounds in cardioprotection through action on the epigenome. Eur Heart J. 2019;40(7):575-82. 